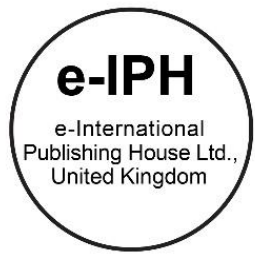

\title{
Inducing Website Design Innovation towards Customer Loyalty
}

\author{
Noorriati Din*, Lennora Putit, Muhammad Naqib Mohd Noor \\ Faculty of Business Management, Puncak Alam UiTM Campus, 42300 Selangor Malaysia
}

\begin{abstract}
Having an attractive and innovative web design could serve as a basis for both offline and online retailers to provide detailed information towards satisfying potential buying intention amongst online shoppers, and subsequently contribute traffic flow to the intended website. This study revealed that both graphic design and social cues attributes were found to have a positive and significant relationship with customer loyalty. Given the valuable experience to the site, the aim of this study is to investigate the extent to which website design attributes affects customer loyalty towards a particular brand or product.
\end{abstract}

(C) 2016. The Authors. Published for AMER ABRA by e-International Publishing House, Ltd., UK. This is an open access article under the CC BY-NC-ND license (http://creativecommons.org/licenses/by-nc-nd/4.0/).

Peer-review under responsibility of AMER (Association of Malaysian Environment-Behaviour Researchers), ABRA (Association of Behavioural Researchers on Asians) and CE-Bs (Centre for Environment-Behaviour Studies), Faculty of Architecture, Planning \& Surveying, Universiti Teknologi MARA, Malaysia.

Keywords: Website design; social cue design; grahic design; customer loyalty

\section{Introduction}

The Internet technology has been widely utilized and mobilized in the 21 st-century environment thus far. In spite of the progressive improvement within this virtual realm, the most common service offered is a 24/7 internet accessibility at anywhere and anytime via its connectivity. The century progress is to a certain extent, privileged by the internet technology towards revolutionizing the way people communicate and interact nowadays. Since the Internet inception, it has been a global platform for communication, commercial and other activities related to its usage. Its usefulness relies very much on information provider due to its myriads of data and information retrievable anywhere and anytime for users' activities. As such, efforts to advance Internet technology are continuously carried out to include creativity and innovation to adapt to challenges of the internet users. One such effort is in the designing of a website as it has become a norm for today's business operations to mobilize the commercial activities and resources online. On that note, the Internet is aimed to serve the user functionality of online shopping, to which online marketing consequently becomes the trend for Internet buyers (Lee \& Putit, 2013). The phenomenon of

\footnotetext{
* Corresponding author. Tel.: +6-019-614-3315

E-mail address: yati_edc@yahoo.com
}

2398-4287 @ 2016. The Authors. Published for AMER ABRA by e-International Publishing House, Ltd., UK. This is an open access article under the CC BY-NC-ND license (http://creativecommons.org/licenses/by-nc-nd/4.0/).

Peer-review under responsibility of AMER (Association of Malaysian Environment-Behaviour Researchers), ABRA (Association of Behavioural Researchers on Asians) and cE-Bs (Centre for Environment-Behaviour Studies), Faculty of Architecture, Planning \& Surveying, Universiti Teknologi MARA, Malaysia.

DOI: http://dx.doi.org/10.21834/e-bpj.v1i3.370 
shopping via online or e-commerce becomes the inspiration for website designers or builders to provide every feature for online shopping to attract customers to buy online, eventually, leading the product loyalty of the business for online shoppers (Al Mowalad \& Putit, 2012, 2015). Loyalty defined by Zeithaml, Berry and Parasuraman (1996) as the intention to perform a various set of behaviors that signal a motivation to maintain a relationship with the focal firm, including allocating a higher share of wallet to the particular service provider, engaging in positive word of mouth, and repeat purchasing". Past studies have found that online shopping through the company's website has shown a satisfactory performance for its online business. Hence, this study is to seek the innovation elements of website design relationship focusing on the graphic design and social cue design features to induce shopper's loyalty of the business.

Nowadays, websites are used to give services to their consumers with an intention to build customer relationship to attract them for repeated purchases. Repeated purchase ultimately creates product loyalty that flourishes the business. Maintaining customer loyalty can effectively maintain profit and increase business performance eventually the financial health of the enterprise. Therefore, safeguarding customer loyalty is important to sustain business success. Tlapana (2009) and Putit et al. (2011) found that poor level of customer service can negatively impact a business. In other words, if a customer does not get fast and efficient services, customers will switch behavior by going to another business that offers fast, convenient and better services. Loss of customers can affect revenue losses that will then impact on the business profitability performance of any business entity. In an effort to look into website design innovation and its influence on consumer loyalty, several research objectives were identified as follows: firstly, to examine the relationship between graphic design and customer loyalty at a business website; and secondly, to examine the relationship between the social cue and customer loyalty at a business website. Several research questions were further developed firstly, is there a significant relationship between graphic design and customer loyalty at a business website? Secondly, is there a significant relationship between the social cue and customer loyalty at a business website? Thirdly, to what extent does graphic design and social cues designs impact customer loyalty? And finally, which of these design attribute contributed significantly towards customer loyalty?

\subsection{Literature review}

In attempting to answer the research objectives and research questions of this study, a review of literature is extensively discussed and argued in this section with regards to the identified constructs.

\section{Graphic design}

The graphic design has been found to have a significant impact on the customer loyalty towards the brand website. Ngan (n.d) has ruled out four keys for customer loyalty namely retention, referral, reputation and revenue. Retention according to Ngan is a continuation to do business and loyalty to the products or services is not sensitive to the competitive pressure. While referral encourages others to choose the company's products or service where some elements of words-of-mouth persist. The same goes with the reputation where a positive support will increase the interest of other such as the investors, future shoppers just to mention a few. Naturally, repeat purchase will bring revenue to the business. Regarding the graphic design, it usually covers a broad range of factors that include usage of image, logo, and color, to capture the first impression of Internet users for repeated purchases. Graphic design that displayed a three-dimensional, dynamic half-screen size clipart that includes an equal use of a soft color with little brightness and cool tone (Karvonen and Parkkinen, 2001) can produce a well-presented website. In that note, designers have the ability to affect human being live their lives. Karvonen and Parkkinen (2001) defined graphic design as factors that give customer first impression when they come across a website. Several items can be characterized when evaluating a website through the company business, that is, the neat and non-chaotic graphics (Kleiner, 2003). Elements in graphics can attract and create a positive interaction especially on the online site or store (Wang \& Emurian, 2005). Hanner (2002) found that graphic designs that include graphics, colors, and icons were used as an extra element to interact with a customer through information transfer in a passive manner. In general, the first impression of a good business website graphic design is assessed by a customer or any other 
internet users who come across the website. A website that does not use the proper way of design is unlikely to be successful for its purpose (Han, 2002). Concerning a website's graphic design, caution must be considered to critically include the desired purpose of the website as well as the ease of use features for online shoppers when visiting the website. On this note, there is a need for creativity and innovation that is useful for a large amount of the customer traffic flow visiting the business website for a relevant and economic value impact.

\section{Social cue design}

Social cue is part of communication that express other people through a body language or known as non-verbal cues. Interpretation of this type of communication is important as to make people understand better to make a good use or the best first impression. There are many types of social cues such as facial expression, body language, voice intonation just to mention a few. Thus, a social cue is a type of social influence that gives a social process perspective on one's individual or behavior. In the perspective of a website design, the social cue design dimension relates to embedding social cues comprising of a face-to-face interaction and social presence, into web interface via different communication media. The content of social cue design is presented as information via static figure in the form of a picture or any motion cue use such as video clips to attract more consumers (Basso, Goldberg, Greenspan, and Weimer, 2001).

In the use of social cue, it has been largely being supported by the commercial website (Massara, 2012). Constantinides (2004) and Klein (2003) stated that social cues design and social capital variables are relevant variables in the international market share and further added that those two variables are a natural element in the increase of the market. Social cues in its generic term refer to a resource that actors derive from a specific social structure and use to pursue their interest; it creates changes in the relationship between the actors. (Postman (2009) and Bessant et al. (2003) have emphasized on the critical impact of learning and social network in driving improved supply chain performance. A website that has a low level of a human interaction must have enough socialcue to manage interaction between the retailer and the customer (Wang \& Emurian, 2005).

\section{Customer loyalty}

The importance of customer loyalty in an electronic platform has received many acknowledgments in various research analyzed in detail (Lynch et al., 2001; Srinivasan et al., 2002; Luarn, and Lin, (2003). Oliver (1999) a classical definition of customer loyalty as an action of a high involvement to commit and purchase and consume a preferred product or service continuously in the future. These activities are causing repetitive same-brand or same brand-set purchasing, despite situational influences and marketing efforts having the potential to cause switching behavior. Ribbink et al. (2004) on the other hand, provides a definition that applies to the online loyalty.

Ranaweera and Neely (2003) found that the behavioral and attitudinal dimensions were the two elements that link in the creation of the customer loyalty. The behavioral and attitudinal dimensions suggested in the literature revealed a link between purchase intentions. Purchase intention also links to customer loyalty where the defination as the tendency to purchase a product or service at some point in the future (Ranaweera and Neely, 2003). Customer loyalty is also defined as customer commitment, that is, a strength of relational ties that wish to maintain a relationship (Bansal et al., 2003). The creation of customer loyalty can also be established through word of mouth. Words of mouth defined by Arndt (1967) is an oral, one to one communication that involved a person who speaks and a receiver of whom perceives the message as a non-commercial on a brand, product or service. Given the above, several research hypotheses were developed for this study firstly, there is a significant positive relationship between graphic design and customer loyalty at a business website. Secondly, there is a significant positive relationship between the social cue and customer loyalty at an enterprise website. Thirdly, graphic design significantly affects customer loyalty and lastly, social cues design significantly affects customer loyalty.

The research framework in Figure 1 consists of three variables namely graphic design and social cues design as being the independent variables while the dependent variable is the customer loyalty. Meanwhile, $\mathrm{H} 1$ and $\mathrm{H} 2$ are the corresponding hypotheses tested in this study. 


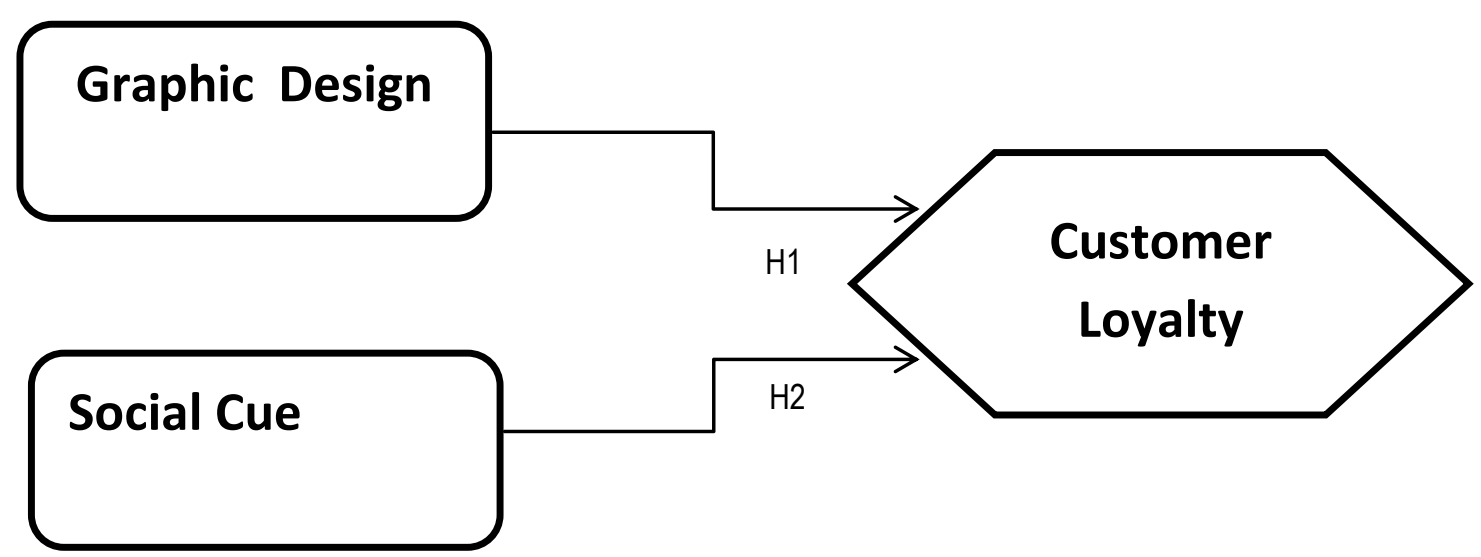

Fig. 1. The Research Framework

\section{Methodology}

This study applied a quantitative research design to investigate the interrelationship of the attributes of website design with customer loyalty. The identified business website for this study is a prominent local bookstore in the state of Selangor, Malaysia that operates both offline and online business. The measurement tool used for this study is a survey questionnaire. Convenience sampling via mall intercept technique is used, the targeted respondents comprising of 200 participants were shoppers who have shopped online at this business website. Most of the item measurements that used in this study consist of an established item adopted from previous research with highreliability scores. The reliability scores for the three constructs were considered high ranging from 7.6 for graphic design, 8.0 for social cues design and 7.6 for customer loyalty.

\section{Data Analysis}

\section{Descriptive analyses}

Out of 200 respondents surveyed, only 150 were considered usable and valid for further data analysis. As illustrated in Table 1.0, the respondents have an equal distribution regarding gender with male respondents at $50.7 \%(\mathrm{~N}=76)$ and female respondents at $49.3(\mathrm{~N}=74)$. Concerning marital status, a majority of them were single at $40 \%(\mathrm{~N}=60)$, aged between the range of $26-35$ years at $41 \%(\mathrm{~N}=62)$. Most of the respondents' occupational status were from the government sectors at $38 \%(\mathrm{~N}=57)$ followed by those in the private sector at $30 \%(\mathrm{~N}=45)$ and students at $21.3 \%(\mathrm{~N}=32)$. Regarding the educational background, a majority of the respondents have at least a degree qualification at $64 \%(\mathrm{~N}=96)$ while racial domination comes from the Malay ethnic group at $67.3 \%(\mathrm{~N}=101)$. The respondents mostly have a monthly income of RM2000.00 and below at $42.7 \%(\mathrm{~N}=64)$, and that majority spent between RM20.00 to RM40.00 at $28.7 \%(\mathrm{~N}=43)$.

Table 1. Demographic Profile of Respondent

\begin{tabular}{llll}
\hline & Demographic & Frequency & Percentage $(\%)$ \\
\hline \multirow{2}{*}{ Gender } & Male & 76 & 50.7 \\
& Female & 74 & 49.3 \\
Marital status & Single & 60 & 40.0 \\
\hline
\end{tabular}




\begin{tabular}{|c|c|c|c|}
\hline & $\begin{array}{l}\text { Married } \\
\text { Married with } 5 \text { kids or less } \\
\text { Married with } 5 \text { kids or more }\end{array}$ & $\begin{array}{l}58 \\
27 \\
5\end{array}$ & $\begin{array}{l}38.7 \\
18.0 \\
3.3\end{array}$ \\
\hline Age & $\begin{array}{l}20 \text { years }-25 \text { years } \\
26 \text { years }-35 \text { years } \\
36 \text { years }-45 \text { years } \\
46 \text { years }-55 \text { years } \\
56 \text { years and above }\end{array}$ & $\begin{array}{l}58 \\
62 \\
23 \\
6 \\
1\end{array}$ & $\begin{array}{l}38.7 \\
41.3 \\
15.3 \\
4.0 \\
0.7\end{array}$ \\
\hline Occupation & $\begin{array}{l}\text { Government sector } \\
\text { Private sector } \\
\text { Self-employed } \\
\text { Student }\end{array}$ & $\begin{array}{l}57 \\
45 \\
16 \\
32\end{array}$ & $\begin{array}{l}38.0 \\
30.0 \\
10.7 \\
21.3\end{array}$ \\
\hline Education Background & $\begin{array}{l}\text { Diploma } \\
\text { Degree } \\
\text { Master } \\
\mathrm{PhD}\end{array}$ & $\begin{array}{l}34 \\
96 \\
16 \\
4\end{array}$ & $\begin{array}{l}22.7 \\
96.0 \\
10.7 \\
2.7\end{array}$ \\
\hline Race & $\begin{array}{l}\text { Malay } \\
\text { Chinese } \\
\text { Indian }\end{array}$ & $\begin{array}{l}101 \\
41 \\
8\end{array}$ & $\begin{array}{l}67.3 \\
27.3 \\
5.3\end{array}$ \\
\hline Income & $\begin{array}{l}\text { Below RM } 2000 \\
\text { RM } 2001 \text { - RM } 4000 \\
\text { RM } 4001 \text { - RM } 6000 \\
\text { RM } 6001 \text { - RM } 8000 \\
\text { Above RM } 8000\end{array}$ & $\begin{array}{l}64 \\
54 \\
20 \\
7 \\
5\end{array}$ & $\begin{array}{l}42.7 \\
36.0 \\
13.3 \\
4.7 \\
3.3\end{array}$ \\
\hline $\begin{array}{l}\text { How much do you spend } \\
\text { on one visit? }\end{array}$ & $\begin{array}{l}\text { Below RM } 20 \\
\text { RM } 20 \text {-RM } 40 \\
\text { RM } 40-\text { RM } 60 \\
\text { RM } 60 \text { - RM } 80 \\
\text { Above RM } 80\end{array}$ & $\begin{array}{l}64 \\
54 \\
20 \\
7 \\
5\end{array}$ & $\begin{array}{l}42.7 \\
36.0 \\
13.3 \\
4.7 \\
3.3\end{array}$ \\
\hline
\end{tabular}

\section{Inferential analysis}

Several inferential analyzes were carried out in an attempt to answer the research objectives, hypotheses and research question identified. Using SPSS software version 21.0, an initial correlation analysis was undertaken to examine the relationship between graphic design and customer loyalty $(\mathrm{H} 1)$. The result shows that there is a positive relationship between graphic design and customer loyalty at 0.553 in Table 2.

Table 2. Correlation Analysis 1

\begin{tabular}{|l|l|l|l|}
\hline \multicolumn{4}{|c|}{ Correlations } \\
\hline \multicolumn{2}{|c|}{} & $\begin{array}{l}\text { GRAPHIC } \\
\text { DESIGN }\end{array}$ & $\begin{array}{l}\text { CUSTOMER } \\
\text { LOYALTY }\end{array}$ \\
\hline \multirow{2}{*}{$\begin{array}{l}\text { GRAPHIC } \\
\text { DESIGN }\end{array}$} & Pearson Correlation & 1 & $.553^{* *}$ \\
\cline { 2 - 4 } & Sig. (1-tailed) & & .000 \\
\cline { 2 - 4 } & $\mathrm{N}$ & 150 & 150 \\
\hline \multirow{2}{*}{$\begin{array}{l}\text { CUSTOMER } \\
\text { LOYALTY }\end{array}$} & Pearson Correlation & $.553^{* *}$ & 1 \\
\cline { 2 - 4 } & Sig. (1-tailed) & .000 & \\
\cline { 2 - 4 } & $\mathrm{N}$ & 150 & 150 \\
\hline${ }^{* *}$. Correlation is significant at the 0.01 level (1-tailed). \\
\hline
\end{tabular}


Correlation analysis was further undertaken to determine the relationship between social cues design and customer loyalty $(\mathrm{H} 2)$. The result also shows that there is a positive relationship between graphic design and customer loyalty at $r=0.589$ in Table 3 .

Table 3. Correlation Analysis 2

\begin{tabular}{|l|l|l|l|}
\hline \multicolumn{4}{|l|}{ Correlations } \\
\hline \multirow{4}{|c|}{} & $\begin{array}{l}\text { SOCIAL } \\
\text { CUE } \\
\text { DESIGN }\end{array}$ & $\begin{array}{l}\text { CUSTOMER } \\
\text { LOYALTY }\end{array}$ \\
\hline SOCIALCUE DESIGN & Pearson Correlation & 1 & $.589^{* *}$ \\
\cline { 2 - 4 } & Sig. (1-tailed) & & .000 \\
\cline { 2 - 4 } & N & 150 & 150 \\
\hline CUSTOMER BEHAVIOR & Pearson Correlation & $.589^{* *}$ & 1 \\
\cline { 2 - 4 } & Sig. (1-tailed) & .000 & \\
\cline { 2 - 4 } & N & 150 & 150 \\
\hline \multirow{2}{*}{ **. Correlation is significant at the 0.01 level (1-tailed). } \\
\hline
\end{tabular}

Subsequently multiple regression analysis was carried out to determine the extent to which graphic design and social cues design affect customer loyalty, and to further identify the most significant factor that contributes towards customer loyalty. The result revealed that about $42 \%$ of total variance of customer loyalty influenced by both graphic design and social design attributes as shown in Table 4 . Another $58 \%$ contributed by other predicting variables not identified in this study. Table 5 indicates that the most significant factor affecting customer loyalty is social cues at $\beta=.406$ and significantly at $\leq 0.001$.

Table 4. Multiple Regression - Model Summary

\begin{tabular}{|c|c|c|c|c|}
\hline Model & $\mathrm{R}$ & $\mathrm{R}$ Square & $\begin{array}{c}\text { Adjusted R } \\
\text { Square }\end{array}$ & $\begin{array}{c}\text { Std. Error of } \\
\text { the Estimate }\end{array}$ \\
\hline 1 & $.648^{\mathrm{a}}$ & .420 & .408 & 2.10586 \\
\hline
\end{tabular}

Table 5. Multiple Regression Analysis - Coefficients

\begin{tabular}{|c|c|c|c|c|c|c|c|c|}
\hline \multirow[t]{2}{*}{ Model } & \multicolumn{2}{|c|}{ Unstandardized Coefficients } & Standardized Coefficients & \multirow[t]{2}{*}{$t$} & \multirow[t]{2}{*}{ Sig. } & \multicolumn{3}{|c|}{ Correlations } \\
\hline & B & Std. Error & Beta & & & Zero-order & Partial & Part \\
\hline (Constant) & 5.695 & 1.751 & & 3.253 & .002 & & & \\
\hline $1 \quad G D$ & .422 & .110 & .343 & 3.853 & .000 & .543 & .364 & .298 \\
\hline SC & .459 & .101 & .406 & 4.564 & .000 & .575 & .420 & .353 \\
\hline
\end{tabular}

\section{Discussion}

The era of the 21 st century often associated with the digital age of technology. Digital delivery is one major influence that forms the basis for online shopping in today's' modern business. Innovation in a general term referring to any improvement to the physical or the technological process to produce the products or services. In other words, bringing to a new practice due to the enhanced development of the product and services produced. While Klein (2002), identifies object-related and process-related dimension in innovation. In the literature, the innovation sees it as trying something new and different. Since business growth depends much on its drivers such the customer and 
the market demands, innovation is a keyword that draws attention to the ability to remain competitive to keep ahead from the competitors. In grasping the potential of the information and communication technology, many businesses have optimized its usage of doing business online. The online business gives rise to the e-commerce development, and one such development is the online shopping. Online shopping is a form of business initiated through electronic medium of the Internet. The electronic medium would mean that the customer can go anywhere to get information for products and services to start at a particular spot or a website. This type of business is particularly relevant in a modern society that provided with electronic marketplace over the web. On that note, online business activities participation showed a rapid growth as customer enable to collect fast and secure information not only to conduct business but to communicate with suppliers (Teece, 2009). The best available destination for the customer to get the support is the business website. On the other hands, this paper is to address findings relatives to website designs. As outlined in the previous paragraph above, this study sought to answer the objectives mentioned.

From the result attained, it shows that the analysis of the demographic respondent perceived behavior is changing and exposed to the environment they lived. It is interesting to note that a distinct pattern of online shoppers emerged whereby the male customers seems to dominate the female shoppers in Table 1. This finding is relevant to a study conducted by Coverdale and Morgan (2011) showing that female is less favorable to do online shopping. Meanwhile, single customers showed the highest frequency to be an online shopper due to their convenience at home or office. The finding shows that single person is more of avoiding expenses to be fare of being single. From the study also, the government sectors to be the most online shoppers followed by the private sectors not far behind. A more educated customer of at least at a degree level seems to dominate the survey on online shopping that consists of $60 \%$ of the sample surveyed in Table 1 above. Regarding the national races, Table 1 revealed that the Malays are taking the lead as they make up the biggest community in the country. They are the younger generation between the ages of 26 to 35 . This paper finding is relevant to study conducted by Noorriati et.al (2012) whereby the age range for technical savvy is within the range mentioned. Based on the framework of this study, it revealed that the independent variables of graphic design and social cues design have a strong relationship with the dependent variable of customer loyalty as shown in Table 2 and Table 3 above. The graphic design and the social cues design are measured directly towards customer loyalty using multiple items in the questionnaire Figure1. In other words, both of the independent variables describe the amount of customer visiting the business websites for continue purchase and the degree of being loyal to the products and services of the business. The social cues have the most significant factor in the relationship that does not have a direct translation to people need to place a particular attention when designing a website for business. In other words, there is a need for a psychological climate conducive for the customers towards shopping online. Therefore, the research findings have put forth an important guideline for a website designer when building a business website when making a decision on online shopping.

\section{Conclusion}

While Internet accessed spurring rapidly with the increased provision of broadband by the government, it is anticipated that future forecast of online or digital shopping will continue to expand. Therefore, a proper understanding for the business provider to identify the marketplace for its products and services before making a decision to go online. This study has shown that there is a significant positive influence on people to be loyal if elements such as graphic design and the social cue are given priority when building a website. It is not only will attract shoppers to stop and browsing the website sites but also, increased customer traffic flow and words of mouth of customer experience are likely to purchase. It is important to note that the vast experience depends on the contents as they pay more for a better experience and more likely to remain loyal. At that point, it is expected the process of website design addresses multiple perspectives by adding more variables besides graphic designs and social cues design to measure its success. Therefore, in leveraging the competition among online business players, the creativity and innovation are the two elements to ensure the success of the implementation. Furthermore, customers' understanding of how the business website works is critical to increase the user's understanding towards the website they visited. Consequently, increased satisfaction significantly towards loyalty. It is interesting to note 
that the quantitative method is more displaying tables and figures to emphasize objective measurements and the statistical result achieved. In other words, only what to look for in tables and figures, therefore, for future studies there is a need to change the perspective in the method used as to get more complex data to understand the changing of human behavior. Finally, online shopping will also prepare the customers for other tasks as information is being formatted for online delivery to become a primary method of virtual communication in the future.

\section{References}

A. Al- Mowalad \& L. Putit (2012). Factors influencing Saudi consumers' behaviour to make online purchase, International Conference on Management, Behavioral Sciences and Economics Issues (ICMBSE'2012) Proceedings, Penang, Malaysia, 11th - 12th February 2012, ISBN: 978-81-922428-5-9

Al Mowalaed,A. \& Putit, L (2013), Factors affecting Saudi Arabian Women's Shopping Behaviour in Online Purchase Activities, Journal of Emerging Economies and islamic Research (ISSN number : e - ISSN 2289 - 2559)

Bansal, S., and Gupta, G. (2001), "Building Customer Loyalty Business-to- Business Commerce". In J. N.Sheth, A. Parvatiyar \& G. Shainesh, eds., Customer Relationship Management, New Delhi, TataMcGraw-Hill, 2001, pp. 3-25

Bessant, J.; Kaplinsky, R. and Morris, M. (2003). Developing capability through learning networks Source: International Journal of Technology Management \& Sustainable Development, Volume 2, Number 1, 1 March 2003, pp. 19-38(20)

Constantinides, E. (2004) "Influencing the online consumer's behavior: the Web experience", Internet Research, Vol. 14 Iss: 2 , pp.111 - 126

Coverdale, T. S. and Morgan, J. A, "The Influence of Identity Characteristics on E-Shopping Enjoyment and E-Loyalty among Women Online Shoppers" (2011). AMCIS 2011 Proceedings - All Submissions. Paper 224. http://aisel.aisnet.org/amcis2011_submissions/224

Hanner, D. (2002). Date retrieved 25/12/2015 from https://www.behance.net/KellyHanner

Kleiner, E. (2003) Considerations for internet "e-Businesses" In Abrams, Rhonda. The successful business plan (4th ed., pp.343-362). Palo Alto, CA: Planning Shop.

Lee, S.C., Putit, L. (2013). A Study on the Acceptance of Mobile Marketing in Malaysia, 14th Annual Global Information Technology Management Association (GITMA) World Conference 2013, 16-18th June 2013, Pullman Hotel and Resort, Putrajaya, MALAYSIA

Luarn, P. and Lin, Hsin-Hui. (2003) A CUSTOMER LOYALTY MODEL FOR E-SERVICE CONTEXT Journal of Electronic Commerce Research, VOL. 4, NO. 4, 2003

Massara, F; Ancarni, F; Costabile, M \& Ricotta, F. (2012). Social Desirability in Virtual Communities. International Journal of Business Administration. Date retrieved 28 february 2016 from www.sciedu.ca/journal/index.php/ijba/article/download/1967/1038

Ngan, M. (n.d). The four Keys to Customer Loyalty. Date retrieved 26/12/2015 from http://www.bhcc.mass.edu/media/03-documents/Four-KeysTo-Customer-Loyalty.pdf

Noorriati Din; Saadiah Yahya and Shireen Haron (2012). Information Retrieval and Academic Performance among Facebook Users. Proceeding paper at AicE-Bs 2012 Cairo, ASIA Pacific International Conference on Environment-Behaviour Studies, Mercure Le Sphinx Cairo Hotel, Giza, Egypt, 31 October - 2 November 2012. "Future Communities: Socio-Cultural \& Environmental Challenges"

Oliver, R. L. (1999), "Whence Consumer Loyalty?," Journal of Marketing, 63 (4), 33-44.

Postman, J. (2009). Social Corp: Social Media goes corporate. Published at Berkeley. CA 94710

Putit, L., A. Karim, NFA, \& Zainuddin, N. (2011) Investigating the relationship between service quality and customer satisfaction: An empirical perspective on pharmaceutical healthcare sector. In Proceedings of 2011 International Conference on Business, Engineering and Industrial Application (ICBEIA2011), Renaissance Hotel, Kuala Lumpur, IEEE Catalog Number: CFP1178P-PRT; ISBN: 978-1-4577-1279-1; IEEE Indexed

Ranaweera, C and Neely, A. (2003).Some moderating effects on the service quality-customer retention link. International Journal of Operations \& Production Management Vol. 23 No. 2, 2003 pp. 230-248. http://www.em eraldinsight.com/0144-3577.htm

Ribbink, D. Riel, A. C. R. V., Liljander, V. and Streukens, S. (2004). Comfort your online customer: quality, trust and loyalty on the internet. Managing Service Quality, Vo1.14, No. 6; 446-644. 
Srinivasan, S.S.; Anderson, R and Ponnavolu, K (2002). Customer loyalty in e-commerce: an exploration of its antecedents and consequences. Journal of Retailing 78 (2002) 41-50

Teece, D. J. (2009). Business Models, Business Strategy and Innovation. Published by Elsevier Ltd. doi:10.1016/j.Irp.2009.07.003

Tlapana, T. P. (2009). Store Layout And Its Impact On Consumer Purchasing Behaviour At Convenience Stores In Kwa Mashu. Dissertation submitted in partial fulfillment of the requirement for the Masters Degree in Technology (Marketing). Marketing, Retail and Public Relations Department, Durban University of Technology.

Wang, Y. D. and Emurian, H.H. (2005). An overview of online trust: Concepts, elements, and implications. Computers in Human Behavior 21 (2005) 105-125. www.elsevier.com/locate/comphumbeh

Zeithmal, V.A; Berry, L.L and Parasuraman, A. (1996).The behavioral consequences of service quality. Journal of Marketing Vol. 60 (April 1996), pg 31-46. 